\title{
A Comparative Study on Sino-UK Postgraduate Professional Degree Education and Implications
}

\author{
Muchun Wan ${ }^{1} \&$ Wenzhong $\mathrm{Zhu}^{2}$ \\ ${ }^{1}$ Postgraduate Student of English for International Business, Guangdong University of Foreign Studies, China \\ ${ }^{2}$ School of Business, Guangdong University of Foreign Studies, China \\ Correspondence: Professor Wenzhong Zhu, School of Business, Guangdong University of Foreign Studies, \\ Guangzhou, 510420, China. E-mail: wenzhong8988@sina.com
}

Received: April 24, 2018; Accepted: May 4, 2018; Published: June 20, 2018

The research is financed by Guangdong Provincial Department of Education with the Teaching Reform Project (127-XCQ16264).

\begin{abstract}
Chinese postgraduate professional degree education has undergone 26 years of development, and has achieved a great progress. But compared with the developed nations in the world, China is still in its infantry stage, and needs to learn from the western developed countries' experiences in this field. This paper makes a comparative analysis of the differences between China and UK in postgraduate professional degree education. It finds that there are significant differences between the two countries in the aspects of programme setting, schooling duration, admissions, curriculum design, teaching delivery, quality control system, etc. The findings imply that China should try to give more authority to universities in programme setting and admissions, and Chinese universities should innovate ways of teaching delivery and systems of quality control.
\end{abstract}

Keywords: postgraduate professional degree education, Sino-UK, comparative analysis, implications

\section{Introduction}

Professional degree refers to the higher education programme aiming to cultivate the talents or professionals fit for a specific field of profession with applied orientation and practical ability, which differs from the academic or research degree programme aiming to cultivate researchers or talents with academic research ability. In fact, postgraduate professional degree education and academic degree education are master degree programmes of the same level, but with different teaching objectives and ability-fostering priority. Postgraduate professional degree education is simply an higher education system which puts more emphasis on professional development orientation, enhances the building of practical application capacity, and meets the realistic needs of social and economic development, such as MBA (Master of Business Administration), MIB (Master of International Business), and MTI (Master of Translation and Interpreting), etc.

China first launched its postgraduate professional degree programme, namely MBA, in 1991. Since then, this type of education has passed over 25 years and established over 39 programmes, covering nearly all fields of the national economic and social development with the comprehensive system of three-level professional education including Doctor, Master and Bachelor. In recent years, with the increasing need of the society for high-level professionals, China enters a new era of fast development in postgraduate professional degree education. China's Ministry of Education has recently implemented an education strategy, which is to enlarge the scale of professional degree education to match and exceed that of academic degree education. In the developed nations of the west, the postgraduate professional degree education has been well-developed to account for about $70 \%-80 \%$ of their total postgraduate students. Taking the US as an example, from the end of the World II to the 1990s, the total number of professional degree graduates had exceeded $55 \%$ of the total postgraduate students. Since 2009, the number of the US' postgraduate professional degree graduates has been more than $70 \%$ of the total. In addition, according to the UK education data announced in the media, since 2003, the number of taught master degrees (professional degree) awarded each year has been over $75 \%$ at an average. Taking the University of Lancaster as an example, based on the author's talk with Geraint Johnes who is the director of postgraduate studies in 2013, the university's 
taught master degree students at schooling took up about $85 \%$ of its total postgraduate students, among whom were the doctor degree students of research.

In current China, however, the Ministry of Education has made a pilot study on the 64 universities' professional degree education practices as the nation's experimental institutions from seven aspects of reforms in terms of curriculum design, research projects and internships, labs, teaching staff, evaluation methodology, teaching committee construction, as well as degree-awarding system.

At the same time, the academic research field has also done some studies on the higher education practices of developed nations such as the UK. For example, Zhu Jingren (1997) makes a review of the UK's higher education practices and finds its high education has been well developed to offer learning opportunities for majority citizens. Zhang Yantong (2000) makes a study on the two modes of learning in the British higher education such as the mode of "capacity-fostering announcement" and the mode of "action-based learning" and argues these modes have some practical enlightenments for Chinese professional degree education. Liu Hui (2001), Liu Yingjun (2008), Han Qiang, Wei Hong, Zhong Binling and Jing Mei (2009), Zhong Guoxiang, Yuan Tangming (2012), and so forth, have all made some studies on the quality control and evaluation system of the UK's higher education, and argue that its external examination system for the quality control of postgraduate education may have some references for China. In addition, Lu Shuangying, Wang Jinghua and Wang Liang (2005), Ke Yuzhen and Yuan Renqing (2006), and Zheng Changling (2007) make an analysis and reflection of the UK's management system and feature in higher education and conclude that the universities of the UK have strong authority of progamme setting and management with the decentralization of the government. Liu Zhong, Zhang Weiming and Zhang Yong (2007) make an analysis of the UK's characteristics in the education model of innovative and entrepreneurial talents. Li Yongshan (2008) makes comparative study on the student affair administration between China and the UK, and finds the importance of student union in participating university management and protecting student welfare. Wang Zhengliang (2009), Zheng Dan, Liu Mingwei and Wang Junjie (2011), Zhu Wenzhong (2014), and others, have made studies on the management concept and internationalization of the UK's higher education and finds some implications for Chinese universities to learn.

However, as a summary, the above studies and findings are conducted more on the general higher education practices and features of the UK, with very few researches on its professional degree education, not saying the comparative study on the issue between China and the UK. Therefore, in the current China where postgraduate professional degree education is developing with a bigger and bigger stride, actively to research the differences between the two countries in this field of higher education will be of great significance and reference for the promotion of China's reform and development in postgraduate professional degree education practices so as to cultivate the application-oriented high-level professionals for the social and economic progress of the country.

This paper aims to answer the research questions of "what are the differences in postgraduate professional degree education between China and UK?" and "what do such differences imply for China's postgraduate professional degree education in the future?". The analysis will be conducted based on the six dimensions which include programme setting, schooling period, admission system, curriculum design, teaching method, and quality assurance system.

\section{Analysis of Sino-UK Differences in Postgraduate Professional Degree Education}

\subsection{Programme Setting}

There exists an obvious difference in the setting of postgraduate professional degree programmes. The first is the difference in the authority or approval power of a programme: Chinese universities must apply for the approval of the provincial and national education department when setting a new degree programme, while UK universities have the authority or freedom to set a degree prorgamme themselves through their internal approval system of three -level teaching committees including department, school and university. The second is the difference in the naming of programmes: in the UK's universities, postgraduate professional degree programmes are usually called as postgraduate taught or PGT degree programmes while in these programmes are named as postgraduate professional degree programmes. In addition, postgraduate academic degree programmes in China are named as postgraduate research or PGR degree programmes which mainly belong to doctor degree programmes in the UK.

\subsection{Schooling Years}

China and UK have an obvious difference in schooling years of postgraduate professional degree programmes. The fist is the difference of length of schooling years: Chinese universities' postgraduate professional degree programmes usually last 2 years for full time-students and 3 years for part-time students while the UK's master degree programmes last just 1 year for full-time ones and 2 years for part-time ones. However, both countries' 
doctor-level professional degree programmes last 3 years for the full-time and 4 years for the part-time, which are the same.

Furthermore, the degree-awarding system for postgraduate professional degree programmes may also have some clear variations between the two countries in that in current China, after completing the required modules and credits, postgraduate professional degree students will be awarded with either the "dual certificates" of diploma and degree for students who are admitted with passing the national entrance examination or the "single certificate" of degree for students who are admitted without passing the examination. In the UK, the graduates of the programmes will be awarded one single certificate covering both degree and diploma. It is said that Chinese education authority has determined to abolish the "single certificate" system of degree awarding since 2017.

\subsection{Admission System}

China and the UK have some differences in the admission system of postgraduate professional degree students. The first is the difference in admission authority: Chinese universities admit the students according to the quota approved by the education authority each year while the UK universities decide the number of admissions by themselves according to their own capacity and social needs. The second is the difference in admission requirements: Chinese universities' admissions of postgraduate professional degree students must based on the passing of the national entrance examination and the authentic investigation of bachelor degree or required working experiences, for example, MBA candidates, while in the UK, the admissions of the students will not require the passing of entrance examinations as a precondition but need to check the qualifications of credit records, degree certificates, recommendation letters, or working experiences for MBA candidates and English language proficiency certificates for international candidates. However, in China, the admission requirements for international students are similar to those of the UK, in which no examination is required, but Chinese language test results may be required.

\subsection{Curriculum Design}

Great differences are seen between China and the UK in the curriculum design of postgraduate professional degree programmes. It is required by the national teaching committee of each professional degree programme that the modules to be delivered should be more than 10 having with no less than 36 credits, among which the compulsory courses should be over 6 with over 14 credits, the selective ones should be 4 . Dissertation writing does not add any credits. However, in the UK, according to the UK Quality Standard of Higher Education, universities usually open 6 modules with the total credits of 150-180 (see Table 1), among which 1-3 courses are compulsory and 13 courses are selective, with each having 10-30 credits and the dissertation adding 60 credits.

Table 1. Credits generally required for graduation in the UK's postgraduate professional degree programmes

\begin{tabular}{lllll}
\hline Degree & Level & Schooling years & Normal credits required & Minimum credits required \\
\hline Master & 7 & 1 year (2 years part-time) & 180 & 150 \\
Doctor & 8 & 3 years (4 years part-time) & $\begin{array}{l}\text { No requirement but 1-3 basic } \\
\text { courses delivered }\end{array}$ & $\begin{array}{l}\text { No requirement, but 1-3 basic } \\
\text { courses delivered }\end{array}$ \\
\hline
\end{tabular}

\subsection{Teaching Methodology}

The differences between China and the UK in the teaching practice of postgraduate professional degree programme appear to be great although the two countries' postgraduate professional degree programmes have similar focuses on social practice and career orientation. The first difference is seen in the area of teaching materials: Chinese programmes tend to use the core textbooks specified by tutors or programme directors while the UK's programmes usually do not require the given core textbook, but list a number of reference books for students to read. The second difference lies in the teaching method: Chinese ways of course delivery usually attach value to the systematic and detailed explanation or lecture of the related theory and practice, accompanied by the use of teaching modes of case, group discussion and research project. Usually a module lasts about 36-42 teaching hours, with each being 40-45 minutes. However, the UK's ways of course delivery usually conduct a brief lecture or introduction of the related theory and practice, putting more emphasis on the self study of students and the practice teaching of teachers. The teaching hours of each course usually lasts about 10 hours, with each being about one hour.

\subsection{Quality Control System}

There are some significant differences between China and the UK in terms of the quality control system of postgraduate professional degree programmes. The first is the difference in management institutions: Chinese 
universities usually set up the education center of a specific professional degree programme under the school to be in charge of the quality control of the programme with the central power lying in the hand of the school level and the limited power the center. The UK's universities conduct the self control of teaching quality usually with a kind of "triple layer teaching committees" of university, school and department or center respectively in charge of cross-divisional management and cooperation, development strategy and supervision, and programme design and daily quality control. Power is more decentralized to the departmental level. The second is the difference in the requirement of dissertation defense. In China, all the degree programmes are required to conduct dissertation defense. However, in the UK, except of doctor level programmes, degree programmes may not require any form of dissertation defense. The third is the difference in external supervision system: in China, postgraduate professional degree programmes usually have not established a sound external examiner system, but the prrogammes usually appoint some professionals from external firms or organizations to be part-time paper supervisors; in the UK, each programme usually appoint one external examiner to supervise the quality of curriculum design, course teaching, student learning, examination and dissertation, etc. The forth is the difference in student participation: in Chinese universities, students seldom participate in the decision of programmes while in the UK universities, student unions as an independent institution send representatives to attend the teaching committee meetings of all three levels concerning decisions of programmes which may impact students' benefits.

In a brief summary, there are some key differences in the processes and structures used to manage postgraduate professional degree programmes, course design, and delivery, etc. The major differences are summarized in the following table:

Table 2. Sino-UK differences in postgraduate professional degree programmes

\begin{tabular}{|c|c|c|c|}
\hline Item & Sub-item & Chinese universities & UK universities \\
\hline \multirow{2}{*}{$\begin{array}{l}\text { Programme } \\
\text { setting }\end{array}$} & Authority & Education authority approves & University sets itself \\
\hline & Naming & Professional degree programmes & Taught degree programmes \\
\hline $\begin{array}{l}\text { Schooling } \\
\text { duration }\end{array}$ & Years & 2 years full time, 3 years part time & 1 year full time, 2 years part time \\
\hline \multirow[t]{2}{*}{ Admissions } & Quota & $\begin{array}{l}\text { Education authority plans the number of } \\
\text { each university's admissions }\end{array}$ & $\begin{array}{l}\text { University itself determines the number of } \\
\text { admissions }\end{array}$ \\
\hline & Conditions & National entrance examination & Credit records, reference letters \\
\hline $\begin{array}{l}\text { Curriculum } \\
\text { design }\end{array}$ & $\begin{array}{l}\text { Module } \\
\text { and credit }\end{array}$ & $\begin{array}{l}\text { Over } 10 \text { courses with over } 36 \text { credits and } \\
\text { each having } 2-3 \text { credits }\end{array}$ & $\begin{array}{l}6 \text { courses with the total of } 150-180 \text { credits } \\
\text { each of which has } 10-30 \text { credits }\end{array}$ \\
\hline \multirow{2}{*}{$\begin{array}{l}\text { Teaching } \\
\text { method }\end{array}$} & $\begin{array}{l}\text { Teaching } \\
\text { material }\end{array}$ & Specified core textbooks & $\begin{array}{l}\text { Listed reference books with unspecified core } \\
\text { textbooks }\end{array}$ \\
\hline & $\begin{array}{l}\text { Teaching } \\
\text { method }\end{array}$ & $\begin{array}{l}\text { Highly valuing the detailed lecture of } \\
\text { the related theory and knowledge, with } \\
\text { each course lasting } 36-42 \text { hours }\end{array}$ & $\begin{array}{l}\text { Briefly introducing the related theory and } \\
\text { knowledge, valuing self study, with each } \\
\text { course lasting } 10 \text { hours }\end{array}$ \\
\hline \multirow{4}{*}{$\begin{array}{l}\text { Quality } \\
\text { control system }\end{array}$} & Institution & $\begin{array}{l}\text { School sets education center with the } \\
\text { key power held by the school level }\end{array}$ & $\begin{array}{l}\text { University, school and department or center } \\
\text { set triple teaching committees, with the } \\
\text { power more decentralized to the center }\end{array}$ \\
\hline & Evaluation & Testing and dissertation defense & Testing but no dissertation defense \\
\hline & Supervision & Lack of sound external examiner system & Having sound external examiner system \\
\hline & Participation & $\begin{array}{l}\text { Students have limited participation in } \\
\text { teaching committee meetings }\end{array}$ & $\begin{array}{l}\text { Student unions have independent power and } \\
\text { students have sufficient participation in } \\
\text { teaching committee meetings }\end{array}$ \\
\hline
\end{tabular}

\section{Conclusion and Implications}

The paper argues that Chinese postgraduate professional degree programmes launched in 1991 has just passed a history of 26 years, and has achieved a tremendous progress. However, the type of higher education still lags behind that of the developed nations such as the UK. Thus, it is necessary for researchers to conduct a comparative study on the Sino-UK Postgraduate Professional Degree Education so as to shed enlightenments for China.

The study concludes that there are significant differences between the two countries' postgraduate professional degree programmes in the aspects of programme setting, schooling duration, admissions, curriculum design, teaching delivery, quality control system, etc. In terms of programme setting, Chinese universities lack of authority 
themselves while the UK's universities are granted with free authority of programme setting. In terms of admissions, Chinese universities are constrained by national entrance examination and government-approved quota, while the UK's universities are not constrained by these factors. In terms of quality control system, Chinese universities have a very strict system of dissertation defense while the UK's universities do not have such a practice except for doctor degree programmes. In addition, the UK's universities have established a sound system of external examiner and student participation Chinese universities are relatively weak in these areas.

The findings imply that China should try to give more authority and flexibility to universities in programme setting and admissions, and Chinese universities should innovate ways of teaching delivery and systems of quality control, for example, conducting reforms in the areas of practice teaching, dissertation writing and defense system, establishing external examiner system, as well as involving more student participation in teaching committee meetings, etc., so as to facilitate Chinese postgraduate professional degree education to make further progress in the coming years.

What's more, these findings may also provide some references for the UK and other countries to understand the Chinese status of postgraduate professional degree education so that the potential opportunities of higher education cooperation and development can be promoted more successfully.

\section{References}

Chen, H. Q. (2009). Review of the UK Higher Education Quality Control System. Journal of University Research and Evaluation.

Jing, M. (2010). The Quality Evaluation System of the UK Higher Education. Journal of Education. Journal of Higher Education Research.

Lancaster University Manual of Academic Regulations and Procedures. (2012). Retrieved from http://www.lancs.ac.uk

Lancaster University Postgraduate Assessment Regulation. (2012). Retrieved from http://www.lancs.ac.uk

Lancaster University Postgraduate Prospects 2013. Retrieved from http://www.lancs.ac.uk

Liu, H. (2001). The Issue of Quality Evaluation of Higher Education: Experiences and Implications of the UK Higher Education Quality Control and Evaluation. Journal of Foreign Education Study.

Liu, Y. J. (2008). The Enlightenment of the UK Higher Education Evaluation System. Journal of Liaoning Administration Institute.

Liu, Z., Zhang, W. M., \& Zhang, R. (2007). Research on the Creative Talent Education Model of the UK Higher Education. Journal of Higher Education Research.

Lu, S. Y. (2005). Features and Enlightenments of the UK Higher Education Management. Journal of Tianjin University of Engineering University.

UK Quality Code for Higher Education. (2004). Retrieved from http://www.qaa.ac.uk/assuringstandardsandquality/quality-code

Wang, J. H. (2005). Implications of the UK Higher Education Practices. Journal of International Talent Exchange.

Wang, L., \& Ke, Y. Z. (2015). Implications of the UK's University Development Putting Human Education at the First Place. Journal of Shanghai Education.

Wang, Z. L. (2009). The Enlightenment of the UK Higher Education Concept. Journal of Luoshang College.

Wei, H., \& Zhong, B. L. (2009). Value the Learning Effect of Students and Improve the Efficacy of Education Evaluation: Trends of International Higher Education and Implications. Journal of China Higher Education Research.

Yuan, R. Q. (2006). My Understanding of the UK Higher Education. Journal of Modern Guizhou.

Zhang, Y. T. (2000). Ability Education and Action Learning Mode of UK Higher Education. Journal of Comparative Education Research.

Zheng, C. L. (2016). Changes and Implications of the UK higher Education Teaching Philoshopy. Journal of Modern Business Education.

Zheng, D., Liu, M. W., \& Wang, J. J. (2011). The "Student-centered" Higher Education Concept of the UK. Journal of Education and Teaching Forum.

Zhong, G. X., \& Yuan, T. M. (2012). Research on the Quality Assurance System of the UK Higher Education Based 
on the case of York. Journal of Chongqing Education Institute.

Zhu, J. R. (1997). Review of the British Commonization of Higher Education.

\section{Copyrights}

Copyright for this article is retained by the author(s), with first publication rights granted to the journal.

This is an open-access article distributed under the terms and conditions of the Creative Commons Attribution license (http://creativecommons.org/licenses/by/4.0/). 